\title{
Upwelling Increases Net Primary Production of Corals and Reef-Wide Gross Primary Production Along the Pacific Coast of Costa Rica
}

\author{
Ines Stuhldreier ${ }^{1,2 *}$, Celeste Sánchez-Noguera ${ }^{1,3}$, Florian Roth ${ }^{1,2}$, Jorge Cortés ${ }^{3}$, \\ Tim Rixen ${ }^{1}$ and Christian Wild ${ }^{1,2}$ \\ ${ }^{1}$ Leibniz Center for Tropical Marine Ecology (ZMT), Bremen, Germany, ${ }^{2}$ Faculty of Biology and Chemistry (FB2), University of \\ Bremen, Bremen, Germany, ${ }^{3}$ Centro de Investigación en Ciencias del Mar y Limnología, Universidad de Costa Rica, San \\ José, Costa Rica
}

\section{OPEN ACCESS}

Edited by:

Thomas K. Frazer,

University of Florida, USA

Reviewed by:

Daniel Wangpraseurt, University of Technology Sydney,

Australia

Jose D. Carriquiry

Universidad Autónoma de Baja

California, Mexico

Melissa Susan Roth

University of California, Berkeley, USA

*Correspondence:

Ines Stuhldreier

ines.stuhldreier@uni-bremen.de

Specialty section:

This article was submitted to

Coral Reef Research,

a section of the journal

Frontiers in Marine Science

Received: 01 July 2015 Accepted: 07 December 2015 Published: 23 December 2015

Citation:

Stuhldreier I, Sánchez-Noguera C, Roth F, Cortés J, Rixen T and Wild C

(2015) Upwelling Increases Net

Primary Production of Corals and Reef-Wide Gross Primary Production Along the Pacific Coast of Costa Rica.

Front. Mar. Sci. 2:113.

doi: 10.3389/fmars.2015.00113
Photosynthetic production is a key ecosystem service provided by tropical coral reefs, but knowledge about the contribution of corals and other reef-associated organisms and the controlling environmental factors is scarce. Locations with occurrence of upwelling events can serve as in-situ laboratories to investigate the impact of environmental variability on production rates of reef-associated organisms. This study investigated individual and reef-wide net $(\mathrm{Pn})$ and gross primary production $(\mathrm{Pg})$ for the dominant autotrophic benthic organisms (hard corals Pocillopora spp., crustose coralline algae (CCA), turf algae, and the macroalga Caulerpa sertularioides) associated with a coral reef along the Pacific coast of Costa Rica. Oxygen fluxes by these organisms were measured at a weekly to monthly resolution over 1 year (May 2013-April 2014) via in-situ chamber incubations. The influence of simultaneously measured environmental parameters (temperature, light, inorganic nutrient concentrations, dissolved and particulate organic matter concentrations) on $\mathrm{Pn}$ of the different taxa were tested via linear model fitting. Turf algae showed highest individual $\mathrm{Pn}$ and $\mathrm{Pg}$ rates per organism surface area (35 and $49 \mathrm{mmol} \mathrm{O}_{2} \mathrm{~m}^{-2} \mathrm{~h}^{-1}$ ), followed by Pocillopora spp. (16 and $25 \mathrm{mmol} \mathrm{O}_{2} \mathrm{~m}^{-2} \mathrm{~h}^{-1}$ ), CCA ( 9 and $15 \mathrm{mmol} \mathrm{O}_{2} \mathrm{~m}^{-2} \mathrm{~h}^{-1}$ ), and C. sertularioides (8 and $11 \mathrm{mmol} \mathrm{O}_{2} \mathrm{~m}^{-2} \mathrm{~h}^{-1}$ ). Under upwelling conditions (February-April 2014), Pn rates of all algal taxa remained relatively uniform despite high nutrient availability, Pn of corals increased by $70 \%$. On an ecosystem level, corals on average contributed $60 \%$ of total $\mathrm{Pn}$ and $\mathrm{Pg}$ per reef area (73 and $98 \mathrm{mmol} \mathrm{O}_{2} \mathrm{~m}^{-2} \mathrm{~h}^{-1}$, respectively), due to high benthic coverage, followed by turf algae (25\%). Under upwelling conditions, reef-wide Pg increased by $>40 \%$, indicating acclimatization of local reef communities to upwelling conditions.

Keywords: coral reef, benthic primary production, upwelling, Gulf of Papagayo, eastern tropical Pacific

\section{INTRODUCTION}

Photosynthetic production by benthic organisms represents a key ecosystem service provided by tropical coral reef systems. The conversion of light energy into chemical energy by photosynthesis creates the base of the food web in most terrestrial and aquatic ecosystems (Valiela, 1995; Chapin et al., 2002). In coral reefs, primary production is tightly coupled with efficient utilization and 
regeneration of organic and inorganic nutrients, which allows an unusually high productivity in a nutrient poor environment (Muscatine and Porter, 1977; Hallock and Schlager, 1986). The main benthic primary producers in coral reef systems are scleractinian corals with their endosymbiotic algae, crustose coralline algae (CCA), filamentous turf algae, fleshy macroalgae, and microphytobenthos in the upper layer of reef sediments (Odum and Odum, 1955; Hatcher, 1988). The magnitude of primary production varies greatly within and among coral reefs due to spatial variation in benthic community composition as well as spatial and temporal changes in environmental conditions (Hatcher, 1990; Gattuso et al., 1998). Primary production is mainly determined by three factors: light intensity (Muscatine et al., 1984; Hatcher, 1990), seawater temperature (Hatcher, 1990; Wild et al., 2011), and nutrient availability (Delgado and Lapointe, 1994; Larned, 1998; Schaffelke, 1999). Coral reefs around the world are subject to changes in temperature, aragonite saturation state, and nutrient availability in the near future (Hughes et al., 2003, 2010; Pandolfi et al., 2011), but potential implications for reef primary productivity are rarely studied. Physiological studies on coral reefs that are naturally exposed to high variability in environmental conditions can provide essential information in this context by enabling a direct correlation of primary production rates to changes in water quality related parameters. These natural laboratories furthermore help to assess the acclimatization potential of reefs to a highly variable environment.

At locations with upwelling events, coral reefs are subject to large variations in water chemistry when sub-thermocline water enters the surface layer. The upwelling usually decreases water temperature and $\mathrm{pH}$, while concentrations of inorganic nutrients and dissolved inorganic carbon (DIC) increase (Pennington et al., 2006; Fassbender et al., 2011; Rixen et al., 2012). Upwelled nutrients can increase primary production and phytoplankton concentrations in the water column (D'Croz and O'Dea, 2007), which, in turn, may decrease light availability to the benthos (Kirk, 1994; Van Duin et al., 2001). Upwelling may therefore contrarily affect benthic primary production: higher inorganic nutrient availability may increase photosynthetic activity of benthic algae and coral symbionts, whereas lower water temperature and light levels may decrease photosynthesis of benthic flora. Macroalgal density and production is highly dependent on light and inorganic nutrient availability (Delgado and Lapointe, 1994; Van Tussenbroek, 2011) and upwelling has been shown to increase growth rates of green and brown macroalgae along the northern Pacific coast of Costa Rica due to elevated nutrient concentrations (Fernández-García et al., 2012; Cortés et al., 2014). Turf algae also are important primary producers on coral reefs and may benefit from nutrient pulses due to rapid nutrient uptake rates (Carpenter, 1990). In contrast, corals are usually adapted to oligotrophic environments (Hallock and Schlager, 1986). Although symbiont densities may increase with increasing nutrient concentration and thereby enable higher production rates (Szmant, 2002; Roder et al., 2011), most studies have found that corals are at disadvantage compared to algae when nutrient concentrations are high (Jompa and McCook, 2002; Haas et al., 2009; Vermeij et al., 2010).
This disadvantage could be particularly pronounced within the case of nutrient pulse events that occur as a consequence of upwelling that might be expected to favor fast growing algal species. Cold water stress due to upwelling may have further negative impacts on coral photosynthetic efficiency and pigment concentration (Saxby et al., 2003) and can even cause bleaching of corals (Glynn and D'Croz, 1990; Jiménez, 2001; Saxby et al., 2003).

Primary production in response to upwelling has been previously studied in the Colombian Caribbean (Eidens et al., 2012, 2014) and the Andaman Sea (Jantzen et al., 2013), and in each instance the introduction of subthermocline water to shallow reefs increased primary productivity of reef algae. The temporal resolution of these studies was low, and the relative importance of driving environmental parameters was not evaluated. In this study, we aimed to investigate if upwelling along the Pacific coast of Costa Rica influences in-situ primary production and respiration rates in eastern tropical Pacific coral reefs and which environmental parameters drive the variability in primary production rates of different benthic primary producers. To our knowledge, this is the first study reporting benthic reef primary production in Costa Rica and the eastern tropical Pacific. The main objectives were to (1) quantify organismspecific primary production and respiration rates with high temporal resolution over 1 year, (2) calculate total net and gross primary production of primary producers at the investigated reef site and quantify the relative contribution of each organismic group, and (3) analyze the influence of simultaneously measured environmental parameters on productivity parameters of each organismic group.

\section{MATERIALS AND METHODS}

\section{Study Site and Seasonality}

The study was carried out from 01 May 2013 to 01 April 2014 in a shallow fringing reef at Matapalo in the Gulf of Papagayo, Costa Rica. Matapalo reef extends about $1 \mathrm{~km}$ along the northern coast of the Nicoya Peninsula in the Bay Matapalo (Figure 1) and is influenced by seasonal upwelling. The reef structure is dominated by the branching coral Pocillopora spp. with alternating patches of dead and living carbonate structures in 3-8 $\mathrm{m}$ water depth. An area of $\sim 600 \mathrm{~m}^{2}$ in $4-6 \mathrm{~m}$ water depth with relatively high live coral cover compared to the surrounding area was visited weekly to conduct water samplings and incubation experiments.

The Papagayo region is subject to strong seasonality caused by the intensification of trade winds during the northern hemisphere winter (McCreary et al., 1989; Amador et al., 2006). These northeasterly winds displace surficial water away from the coast and cause upwelling of sub-thermocline cold and nutrient-rich waters to the surface (Fiedler and Talley, 2006; Pennington et al., 2006). Seasonal upwelling decreases mean seawater temperatures from around $28^{\circ}-23^{\circ} \mathrm{C}$ between December and April (Jiménez, 2001; Alfaro et al., 2012). Strong upwelling events are accompanied by drops in $\mathrm{pH}$ (from 8.02 to 7.86 ) and dissolved oxygen concentration (from 228 to $144 \mu \mathrm{mol}$ $\mathrm{L}^{-1}$; Rixen et al., 2012) and peaks in nutrient concentrations 


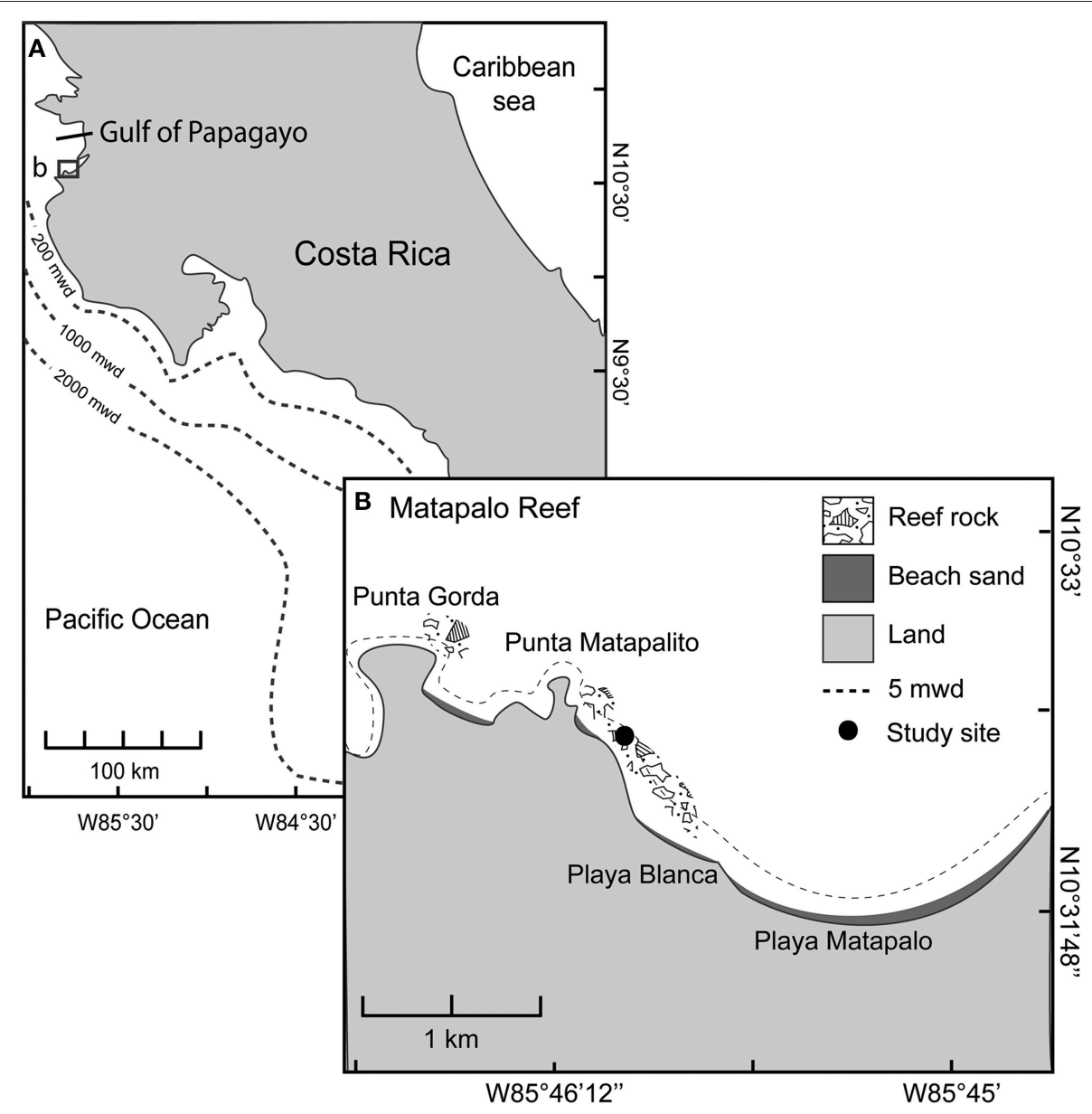

FIGURE 1 | Study site. (A) Location of Matapalo Reef along the northern Pacific coast of Costa Rica. (B) Incubations and benthic surveys took place at $5 \mathrm{~m}$ water depth (mwd) at the indicated study site $\left(10^{\circ} 32^{\prime} 21^{\prime \prime} \mathrm{N}, 85^{\circ} 45^{\prime} 59^{\prime \prime} \mathrm{W}\right)$.

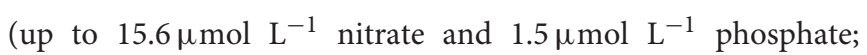
Fernández-García et al., 2012).

\section{Environmental Parameters}

A range of environmental parameters were measured weekly at the study site to characterize upwelling conditions and to investigate the driving factors of primary production on the reef. Water temperature was determined continuously with $\mathrm{HOBO}^{\circledR}$ Pendant Temperature Data loggers and at the time of incubations using an optical dissolved oxygen (DO) sensor (FDO ${ }^{\circledR}$ 925, WTW). Daily temperature range (maximumminimum temperature) was calculated from continuous temperature measurements as a measure of upwelling intensity for each incubation day (Jantzen et al., 2013). Light availability during incubations was measured using a self-contained PAR (photosynthetically active radiation) logger with a planar cosinecorrected sensor (Odyssey Integrating PAR sensor, Dataflow Systems PTY Limited). The logger was placed among the incubation chambers and recorded the incident downwelling photon irradiance between 400 and $700 \mathrm{~nm}$ integrated over 2 min time intervals. The millivolt signal produced by the logger was converted to $\mu \mathrm{mol}$ photons $\mathrm{m}^{-2} \mathrm{~s}^{-1}$ using an exponential fit model according to Long et al. (2012):

$$
\operatorname{PAR}=-4924.7 * \mathrm{e}^{(-\mathrm{ODY} / 20992.9)}+4929.0
$$

where ODY is the raw output data $(\mathrm{mV})$ of the Odyssey data logger multiplied by 7.5 to obtain the same integration time as in the Long et al. (2012) study (15 min). A mean value over each incubation period was calculated for further statistical analyses.

Water for the determination of inorganic nutrient concentrations and dissolved organic carbon (DOC) was sampled in triplicate from directly above the reef structure within glass jars $(500 \mathrm{~mL})$, filtered immediately through syringe filters (pore size $0.45 \mu \mathrm{m}$ ) and stored cool for transportation. Ammonium $\left(\mathrm{NH}_{4}^{+}\right)$was determined fluorimetrically within $24 \mathrm{~h}$ after sampling with a Trilogy ${ }^{\circledR}$ Laboratory Fluorometer/Photometer (Turner Designs) according to Holmes et al. (1999) and Taylor et al. (2007) [detection limit $\left.(\mathrm{LOD})=0.023 \mu \mathrm{mol} \mathrm{L}{ }^{-1}\right]$. Determination of phosphate $\left(\mathrm{PO}_{4}^{3-}\right)$ was conducted spectrophotometrically with the same device following the standard protocol of Murphy and Riley (1962) 
$\left(\mathrm{LOD}=0.033 \mu \mathrm{mol} \mathrm{L} \mathrm{L}^{-1}\right)$. Sub-samples were kept dark and frozen until the end of the study period and were analyzed for nitrate $\left(\mathrm{NO}_{3}^{-}\right)$and nitrite $\left(\mathrm{NO}_{2}^{-}\right)$concentrations using a Thermo Scientific UV Evolution $201^{\circledR}$ photometer based on a method revised by García-Robledo et al. (2014) $\left[\mathrm{LOD}\left(\mathrm{NO}_{2}^{-}\right)=\right.$ $\left.0.151 \mu \mathrm{mol} \mathrm{L}^{-1} ; \mathrm{LOD}\left(\mathrm{NO}_{x}\right)=0.162 \mu \mathrm{mol} \mathrm{L}^{-1}\right]$. Concentrations of $\mathrm{NO}_{2}^{-}$were always below the LOD. For DOC analysis, samples were filtered through pre-combusted glass microfiber filters (VWR, $25 \mathrm{~mm}$, particle retention $0.7 \mu \mathrm{m}$ ) in polycarbonate syringe-filter-holders into acid-washed $30 \mathrm{~mL}$ high-density polyethylene (HDPE) wide-neck bottles and frozen at $-20^{\circ} \mathrm{C}$ within $3 \mathrm{~h}$ after sampling. For analysis, samples were thawed, acidified with $28 \mu \mathrm{L} 33 \% \mathrm{HCl}$ per $30 \mathrm{~mL}$ sample to reach $\mathrm{pH}$ $\leq 2$, and analyzed with a Shimadzu TOC-VCPH + ASI-V elemental analyzer conforming to U.S. EPA Method 415.1 (U.S. Environmental Protection Agency, 1983; Hansell, 1993; LOD = $\left.8 \mu \mathrm{mol} \mathrm{L}^{-1}\right)$.

Water for the analysis of chlorophyll $a(\mathrm{Chl} a)$ and particulate organic matter (POM) concentrations was sampled in triplicate from around $20 \mathrm{~cm}$ below the sea surface above the reef in $3.8 \mathrm{~L}$ plastic containers. Within $2 \mathrm{~h}$ after sampling, subsamples of each container ( $1 \mathrm{~L}$ for chl $a, 2 \mathrm{~L}$ for POM after gentle agitation of containers) were filtered onto VWR glass microfiber filters ( $47 \mathrm{~mm}$, particle retention $1.6 \mu \mathrm{m}$ ) with an electric vacuum pump (max. pressure $<200$ mbar). Directly after filtration, Chl $a$ filters were homogenized in $7 \mathrm{~mL} \mathrm{90 \%} \mathrm{acetone} \mathrm{with} \mathrm{a} \mathrm{glass} \mathrm{rod,}$ and the filter slurry was incubated overnight at $4{ }^{\circ} \mathrm{C}$. Samples were centrifuged for $10 \mathrm{~min}$ at $805 \mathrm{~g}$ before an aliquot of the supernatant was transferred to a glass cuvette. Fluorescence was measured (Trilogy ${ }^{\circledR}$ Laboratory Fluorometer/Photometer) before and after acidification to $0.003 \mathrm{~N} \mathrm{HCl}$ with $0.1 \mathrm{~N} \mathrm{HCl}$ for $90 \mathrm{~s}$. Procedure and calculations were carried out according to U.S. EPA Method 445.0 (Arar and Collins, 1997). The precombusted filters with POM were stored in combusted tinfoil and frozen at $-20^{\circ} \mathrm{C}$ until the end of the study period. Filters were dried for $24 \mathrm{~h}$ at $40^{\circ} \mathrm{C}$ for transport and again for $24 \mathrm{~h}$ at $40^{\circ} \mathrm{C}$ just before analysis. Dried filters were analyzed for total carbon $(\mathrm{C})$, nitrogen $(\mathrm{N})$, and organic carbon $\left(\mathrm{C}_{\mathrm{org}}\right)$ content in a CHN elemental analyzer (Eurovector Euro EA 3000). A quarter of the filter was used for (i) the determination of $\mathrm{C}$ and $\mathrm{N}$ in tin-cups and (ii) $\mathrm{C}_{\text {org }}$ in silver-cups after acidification with $200 \mu \mathrm{L} 1 \mathrm{~N} \mathrm{HCl}$. Precision of analyses was calculated from low soil standard (OAC 187560; C: $\pm 0.032 \%, \mathrm{~N}: \pm 0.004 \%, \mathrm{C}_{\mathrm{org}}: \pm$ $0.046 \%)$. As $\mathrm{C}_{\text {org }}$ was almost identical to total $\mathrm{C}$ over the entire study period, only values for particulate organic carbon (POC) and particulate organic nitrogen (PON) in the water column are provided below. Missing values for DOC and POC/PON at the beginning of the study period (see Figure 5) resulted in smaller sample sizes for some of the fitted models (see Section Correlation of Primary Production and Environmental Parameters). The temporal variability in abiotic parameters at Matapalo and another upwelling exposed reef site is described in more detail in Stuhldreier et al. (2015).

\section{Benthic Community and Study Organisms}

Cover of benthic organisms and substrates at Matapalo reef was quantified monthly at $5 \mathrm{~m}$ water depth along five permanent transects of $10 \mathrm{~m}$ length (marked with iron poles every $5 \mathrm{~m}$ ), using the chain method (Rogers et al., 1994). A $10 \mathrm{~m}$ iron chain with 532 links was placed directly on the reef structure, following its contours, and thereby taking into account the structural complexity of the reef. Benthic cover was determined under each link (live coral and macroalgae to species level, dead coral, CCA, turf algae, cyanobacteria, sand) and the number of links was later converted to relative seafloor cover.

The dominant primary producers in the reef at $5 \mathrm{~m}$ water depth were identified as the scleractinian corals Pocillopora spp. $(35.4 \pm 1.3 \%)$, turf algae $(28.8 \pm 1.4 \%)$, CCA $(29.2 \pm 1.6 \%)$, and the green algae Caulerpa sertularioides $(4.0 \pm 0.7 \%$; mean values \pm SE over the study period). These organisms together accounted for $97 \%$ of the reef coverage and thus were determined to be representative of primary producers on the reef. Four specimen of each organism group were collected for incubation experiments from the reef or the surrounding sand flat using SCUBA on each of the 33 incubation days. Small, loose live coral fragments and dead coral fragments overgrown with CCA could be found easily on the sand and rubble area bordering the reef. Therefore, it was not necessary to break coral colonies or reef structure overgrown with CCA, which would have resulted unnecessary damage to coral or algal tissue. Care was taken to use healthy coral and CCA fragments without abrasion and of similar size to ensure comparable results. Dense turf algae conglomerates were removed from dead coral rock, and $C$. sertularioides was collected as pieces of stolons with associated fronds. All organisms were collected at 4.5-5.5 m water depth.

For surface area quantification of incubated organisms, the average diameter and height of coral fragments, CCA fragments and turf algae conglomerates were measured with a caliper, and surface areas were calculated for all three taxa with the best fitting geometric shape (cylinder; Naumann et al., 2009). In the case of coral fragments we additionally multiplied the result with the proposed approximation factor for Pocillopora spp. (0.94) according to Naumann et al. (2009). Surface area of $C$. sertularioides was calculated by average length $\times$ width of algal fronds, multiplied by the factor 2 to account for both sides, and multiplied by the number of fronds.

\section{Incubation Experiments}

Every week, four specimens of each organism group were incubated immediately after collection with surrounding seawater as medium to quantify individual net primary production (Pn) under in-situ water and light conditions. Incubations took place inside $500 \mathrm{~mL}$ gas-tight glass jars (J. WECK $^{\circledR}$, Germany) within $1-2 \mathrm{~m}$ distance from the reef (Figure 2). Incubations started 10:30-11:30 or 13:30-14:30 when light availability was generally high and did not limit photosynthesis. Time of incubation was not correlated to primary production rates $\left[F_{(28,103)}=0.676, p=0.882\right]$, indicating that different times of incubations did not confound the effects of other parameters. Three incubation chambers containing only seawater served as controls for incubations, while one chamber was closed with the others and immediately brought to the surface to measure the initial concentration of dissolved oxygen (DO) and temperature using an optical DO 


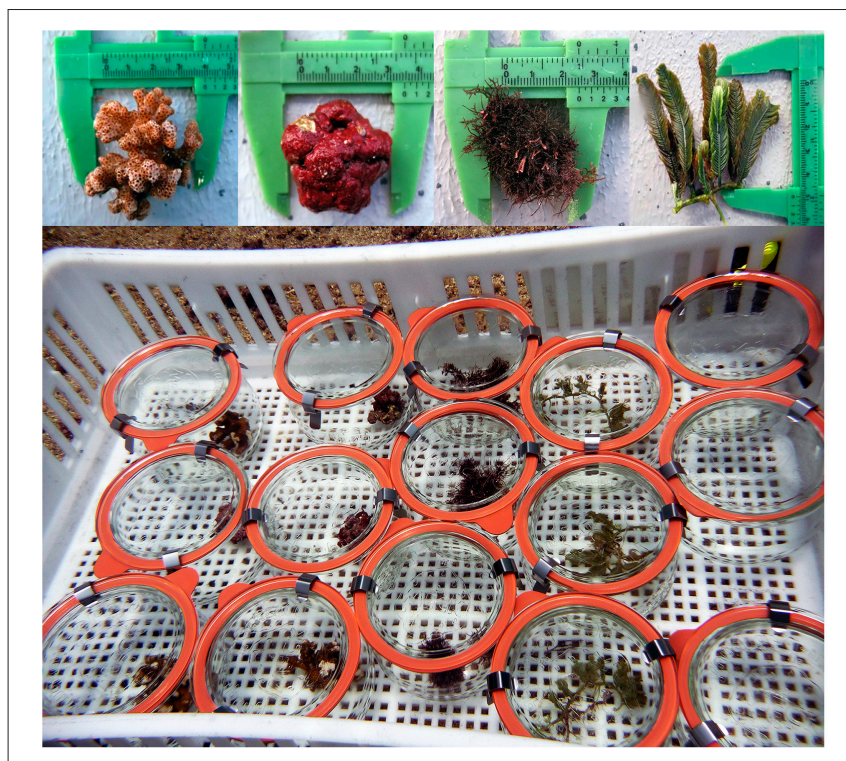

FIGURE 2 | Dominant primary producers and incubation set-up. The upper panel shows the incubated organisms Pocillopora spp., crustose coralline algae, turf algae and Caulerpa sertularioides (from left to right). The lower picture shows the incubation set-up in $5 \mathrm{~m}$ water depth on the seafloor

sensor $\left(\mathrm{FDO}^{\circledR}\right.$ 925, WTW). After approximately $70 \mathrm{~min}$ of incubation, all glass chambers were transported to the surface, and the concentration of DO was measured in the incubation medium of each chamber after gently stirring for 5-10 s until the signal stabilized to ensure homogeneous DO distribution.

Every month, the incubated specimen and four seawater controls were subsequently incubated for around $70 \mathrm{~min}$ in fresh seawater in a dark cooler on the boat to obtain organism-specific respiration rates $(\mathrm{R})$. All incubations were conducted under noflow conditions, which allowed for comparison with previous chamber incubation studies (Jantzen et al., 2013; Naumann et al., 2013; Eidens et al., 2014). As water flow may enhance $\mathrm{O}_{2}$ fluxes (Mass et al., 2010), the results of the field incubations are conservative estimates of in-situ $\mathrm{O}_{2}$ fluxes and should be interpreted accordingly.

\section{Data Analyses and Statistics Organism-Specific Primary Production}

$\mathrm{Pn}$ and $\mathrm{R}$ for each incubated specimen were derived from DO concentration differences in the incubation medium calculated by subtracting start from end concentrations. These results were corrected for DO concentration differences measured in seawater controls and normalized to specimen surface area and incubation period. Gross primary production ( $\mathrm{Pg}$ ) was calculated by adding $\mathrm{R}$ to $\mathrm{Pn}$ for each incubated specimen. This estimation of gross photosynthesis is presumed to be conservative as dark respiration (which was measured) can be $>10$ times lower than light respiration (Al-Horani et al., 2003; Schrameyer et al., 2014).

Rates from specimens of the same taxa and incubation day were averaged, resulting in almost weekly organism-specific Pn ( $n=33$ ) and monthly $\mathrm{R}$ and $\mathrm{Pg}$ rates $(n=12)$, given in $\mathrm{mmol} \mathrm{O}_{2} \mathrm{~m}^{-2}$ organism surface area $\mathrm{h}^{-1}$. The general influence of upwelling on overall and organism-specific Pn and R-values was determined using One-way Analyses of Variance (ANOVA) comparing values obtained between May 2013 and January 2014 (non-upwelling conditions) against values between February and April 2014 (upwelling conditions) using the software R 3.1.1 (R Core Team, 2014). Non-upwelling and upwelling conditions were defined based on significant changes in environmental parameters in the year of observation, mainly temperature and nutrient concentrations (see Section Upwelling Conditions).

\section{Reef-Wide Primary Production}

The contribution of each organismic group to reef-wide Pn and $\mathrm{Pg}$ for each month was estimated as follows (after Eidens et al., 2014):

$$
c_{i}=P_{i} b_{i} s_{i}
$$

Taxa specific $c_{i}$ was thereby calculated from the benthic groups' individual production rate $\left(\mathrm{P}_{\mathrm{i}}\right)$, their respective $2 \mathrm{D}$ benthic cover on the reef $\left(b_{i}\right)$ and group specific mean 2D-3D conversion factors $\left(s_{i}\right)$. The 2D-3D conversion factors were obtained from the literature and were as follows: 6.8 for Pocillopora spp. (Alcala and Vogt, 1997), 2.1 for CCA (Eidens et al., 2014), 1.5 for turf algae (Jantzen et al., 2013), and 14 for C. sertularioides (Naumann et al., 2013). Total reef-wide benthic net (total Pn) and gross primary production (total $\mathrm{Pg}$ ) was calculated by summing up the contributions of individual taxa $\left(c_{i}\right)$ and are expressed as $\mathrm{mmol} \mathrm{O}_{2} \mathrm{~m}^{-2}$ reef area $\mathrm{h}^{-1}$. Total reef-wide $\mathrm{Pn}$ should not be confused with net ecosystem production, which would include respiration of all heterotrophic organisms within the reef system. Differences in total $\mathrm{Pn}$ and $\mathrm{Pg}$ between non-upwelling and upwelling conditions were determined using One-way Analysis of Variance (ANOVA) in the software R 3.1.1 (R Core Team, 2014).

\section{Correlation of Primary Production and Environmental Parameters}

We used model selection in the software R 3.1.1 (R Core Team, 2014) to determine which combination of the 10 measured environmental parameters (incubation temperature, daily temperature range, light, $\mathrm{PO}_{4}^{3-}, \mathrm{NO}_{3}^{-}, \mathrm{NH}_{4}^{+}, \mathrm{Chl} a, \mathrm{PON}, \mathrm{POC}$, and DOC) best predicted the measured overall and organismspecific production rates. Parameters were $z$-transformed and tested for multicollinearity using scatterplot matrices and correlation coefficients based on restricted maximum likelihood estimates. Removing collinearity is important because explanatory parameters may mask each other's influence on the response parameter and reduce the explanatory power of the model. Collinear parameters were removed resulting in six explanatory variables with pairwise correlation coefficients $\leq 0.6$ : temperature (incubation temperature, daily temperature range), light (only for $\mathrm{Pn}$ and $\mathrm{Pg}$ ), nutrients $\left(\mathrm{NH}_{4}^{+}, \mathrm{PO}_{4}^{3-}, \mathrm{NO}_{3}^{-}\right), \mathrm{POM}$ $(P O C$, PON, Chl $a)$, and DOC. The factor which represents their respective group in statistical analyses is indicated in italics. Linear models were fit to $\log (\mathrm{x}+1)$-transformed $\mathrm{Pn}, \mathrm{Pg}$, and $\mathrm{R}$ data including all six explanatory variables. Minimum adequate model selection was then performed using Akaike's Information 
Criterion (AIC) and adjusted $R^{2}$ (indicating the amount of variance in the data explained by the respective model) before being tested for significant influences of remaining parameters using multiple regression with adjusted sum of squares (function "Anova" in package "car"). The models for overall Pn, Pg, and R data included taxa and its interactions with the environmental parameters as explanatory variables, while models for organismspecific Pn rates only tested the influence of environmental parameters. We did not model the influence of environmental parameters on $\mathrm{Pg}$ and $\mathrm{R}$ data of individual taxa, because monthly measurements yielded in only 12 data points per taxa, and assumptions of normality would be violated with this sample size.

\section{RESULTS}

\section{Upwelling Conditions}

Water temperatures at Matapalo reef were relatively constant at $28-29^{\circ} \mathrm{C}$ from May 2013 to January 2014. Between February

TABLE 1 | Environmental parameters under non-upwelling and upwelling conditions.

\begin{tabular}{|c|c|c|c|}
\hline Water parameter & $\begin{array}{c}\text { non-upwelling } \\
\text { May-Jan }\end{array}$ & $\begin{array}{l}\text { upwelling } \\
\text { Feb-Apr }\end{array}$ & $\begin{array}{c}\text { ANOVA } \\
p\end{array}$ \\
\hline Water temperature $\left[{ }^{\circ} \mathrm{C}\right]$ & $28.51+0.05$ & $25.80+0.23$ & ${ }^{*}<0.001$ \\
\hline $\begin{array}{l}\text { Light }[\mu \mathrm{mol} \text { photons } \\
\left.\mathrm{m}^{-2} \mathrm{~s}^{-1}\right]\end{array}$ & $683.16+64.88$ & $595.50+97.45$ & 0.497 \\
\hline Phosphate $\left[\mu \mathrm{mol} \mathrm{L}{ }^{-1}\right]$ & $0.24+0.02$ & $0.46+0.13$ & ${ }^{*} 0.006$ \\
\hline Ammonium $\left[\mu \mathrm{mol} \mathrm{L}{ }^{-1}\right]$ & $0.52+0.03$ & $1.13+0.22$ & ${ }^{*}<0.001$ \\
\hline Nitrate $\left[\mu \mathrm{mol} \mathrm{L}{ }^{-1}\right]$ & $0.42+0.06$ & $1.87+0.73$ & ${ }^{*} 0.001$ \\
\hline Chlorophyll a [ $\left.\mu \mathrm{g} \mathrm{L}^{-1}\right]$ & $0.52+0.07$ & $1.10+0.23$ & ${ }^{*} 0.003$ \\
\hline $\begin{array}{l}\text { Particulate organic } \\
\text { nitrogen }\left[\mu \mathrm{L} \mathrm{L}^{-1}\right]\end{array}$ & $25.59+2.15$ & $59.63+11.52$ & ${ }^{*}<0.001$ \\
\hline $\begin{array}{l}\text { Particulate organic } \\
\text { carbon }\left[\mu \mathrm{g} \mathrm{L}^{-1}\right]\end{array}$ & $215.52+23.75$ & $376.78+68.72$ & ${ }^{\star} 0.007$ \\
\hline $\begin{array}{l}\text { Dissolved organic } \\
\text { carbon }\left[\mu \mathrm{mol} \mathrm{L}^{-1}\right]\end{array}$ & $128.26+9.74$ & $168.31+14.36$ & *0.032 \\
\hline
\end{tabular}

Average values were calculated from all available data points between 01.05.2013 and 01.04.2014 and are given as mean \pm SE. P-Values in the last column derive from the comparison of non-upwelling and upwelling conditions using One-way Analysis of Variance in the software R 3.1.1. Asterisks indicate significant differences $(p<0.05)$. and April 2014, temperatures dropped repeatedly by $2-7^{\circ} \mathrm{C}$ to minimum daily averages of $21^{\circ} \mathrm{C}$ for several days. Drops in temperature in February and March 2014 were accompanied by up to 3-, 4-, and 15-fold increases in phosphate, ammonium, and nitrate concentrations, respectively. Therefore, the time between 01 February and 01 April 2014 was defined as upwelling period in the year of observation. Chlorophyll $a$ concentrations peaked several times in February and March 2014, reaching maximum values of $2.2 \mu \mathrm{g} \mathrm{L}^{-1}$. POC and nitrogen in the water increased by 75 and $130 \%$ under upwelling compared to nonupwelling conditions. DOC concentrations had increased already in December 2013 by around $70 \%$ compared to concentrations between May and December 2013 and stayed elevated until the end of the study period. Under upwelling conditions, water temperature was significantly lower, while inorganic nutrients and all organic matter parameters were significantly elevated compared to non-upwelling conditions (Table 1). Only light availability was constant across upwelling and non-upwelling conditions.

\section{Organism-Specific Primary Production}

The average background photosynthesis of reef water in control chambers was $0.02 \pm 0.01 \mathrm{mg} \mathrm{O}_{2} \mathrm{~L}^{-1} \mathrm{~h}^{-1}$ and did not increase significantly under upwelling conditions $\left(T=145.000, \mathrm{n}_{\mathrm{UPW}}=\right.$ $\left.8, \mathrm{n}_{\text {noUPW }}=25, p=0.720\right)$, despite increased chlorophyll $a$ concentrations in the water column.

Of all investigated functional groups, individual primary production and respiration rates were highest for turf algae, followed by Pocillopora spp., CCA, and C. sertularioides (Table 2). Pn and Pg rates significantly differed among taxa $\left[F_{(3,128)}=62.469, p<0.0001\right.$ and $F_{(3,44)}=44.506, p<0.0001$, respectively], except when comparing CCA and $C$. sertularioides. $\mathrm{R}$ rates significantly differed among taxa $\left[F_{(3,44)}=20.464, p<\right.$ 0.0001] except when comparing Pocillopora spp. and turf algae.

$\mathrm{Pn}$ and Pg rates of Pocillopora spp. significantly increased by $71 \%(\mathrm{Pn})$ and $54 \%$ (Pg)under upwelling compared to non-upwelling conditions $\left[F_{(1,31)}=20.922, p<0.0001\right.$ and $F_{(1,10)}=9.600, p=0.0113$, respectively], while rates of all algae groups stayed constant (Figure 3). Respiration rates increased under upwelling compared to non-upwelling conditions in both Pocillopora spp. and CCA, although these differences were not significant. As a result, $\mathrm{R}$ rates of Pocillopora spp. did exceed those of turf algae under upwelling conditions (Figure 3).

TABLE 2 | Individual primary production and respiration rates of the dominant benthic primary producers.

\begin{tabular}{|c|c|c|c|c|}
\hline & Pn & $\mathrm{Pg}$ & $\mathbf{R}$ & Pn:R \\
\hline Pocillopora spp. & $15.5 \pm 1.1(33)$ & $25.2 \pm 2.2(12)$ & $7.2 \pm 0.7(12)$ & $2.6 \pm 0.2(12)$ \\
\hline $\begin{array}{l}\text { Crustose coralline } \\
\text { algae }\end{array}$ & $8.8 \pm 0.6$ (33) & $14.5 \pm 0.9(12)$ & $4.4 \pm 0.7(12)$ & $3.2 \pm 0.5(12)$ \\
\hline
\end{tabular}

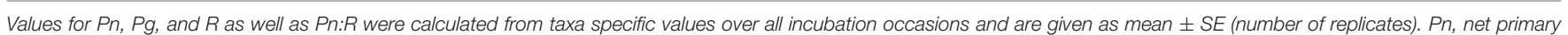
production; Pg, gross primary production; $R$, respiration. 


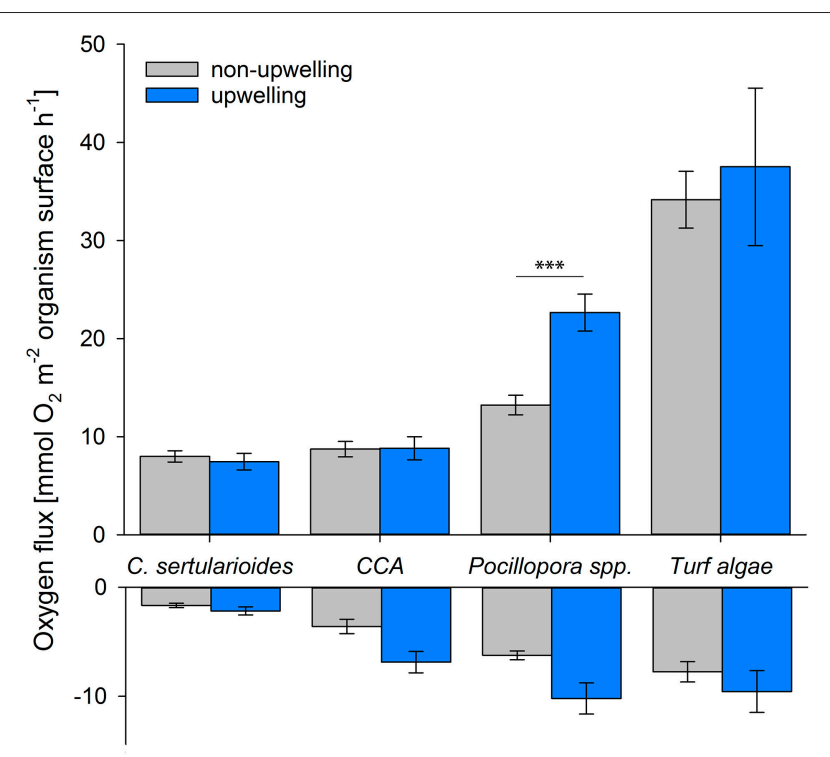

FIGURE 3 | Organism-specific oxygen fluxes. Net primary production (positive) and respiration rates (negative) of the dominant primary producers (in $\mathrm{mmol} \mathrm{O}_{2}$ flux normalized to organism surface area) under non-upwelling (May 2013-January 2014) and upwelling conditions (February-April 2014). ${ }^{* * *} p<0.001$.

Individual respiration rates of all taxa were much smaller than respective net photosynthetic rates, resulting in mean $\mathrm{Pn}: \mathrm{R}$ ratios of around 3 (Pocillopora spp. and CCA) to 6 (turf algae and C. sertularioides; Table 2). While the ratio was relatively uniform over the year of observation for Pocillopora spp., ratios of CCA, turf algae, and C. sertularioides decreased under upwelling (1.7, 4.4, and 4.1, respectively), compared to non-upwelling conditions (3.6, 6.0, and 6.7, respectively), although none of these differences was significant. All statistical results can be found in Supplementary Table 1.

\section{Reef-Wide Primary Production}

The combination of organism-specific production and respiration rates with relative benthic coverage and $2 \mathrm{D}-3 \mathrm{D}$ conversion factors enabled us to calculate total net and gross primary production of all primary producers on the investigated reef at a monthly resolution (Figure 4A). Reef-wide total Pn and $\mathrm{Pg}$ were 33 and $43 \%$ higher under upwelling compared to non-upwelling conditions (Figure 4B). The difference was non-significant for $\operatorname{Pn}\left[F_{(1,10)}=2.874, p=0.1209\right]$, but significant for $\operatorname{Pg}\left[F_{(1,10)}=7.9066, p=0.0184\right]$. The relative contribution of primary producer groups to total Pg was highest for Pocillopora spp. over the whole year of observation (Figure 4D) and significantly increased from $58 \pm$ $2 \%$ under non-upwelling conditions to $73 \pm 3 \%$ under upwelling conditions $\left[F_{(1,10)}=12.315, p=0.0056\right]$, as their individual production rates and benthic cover increased (Figure 4C). The contribution of turf algae to total Pg significantly decreased from $27 \pm 2 \%$ under non-upwelling to $12 \pm 2 \%$ under upwelling conditions $\left[F_{(1,10)}=16.040, p=0.0025\right]$, while relative contributions of CCA and C. sertularioides did not differ significantly between the two time periods (Figure 4D).

\section{Correlation of Primary Production to Environmental Parameters}

Overall and individual oxygen production rates showed considerable variability over the study period, potentially related to the variability in water parameters (Figure 5).

\section{Overall Primary Production and Respiration}

The variability in overall $\mathrm{Pn}$ data was best explained by a model including the explanatory variables taxa, temperature, light, nutrients, DOC, and the interactions between taxa and the parameters temperature and DOC. These variables together explained $71 \%$ of the variability in the data $\left(\operatorname{adj} R^{2}=0.71\right)$ and all parameters except DOC and the two interaction terms significantly influenced overall production rates. The variability in overall $\mathrm{Pg}$ data was best explained by the variables taxa, light, DOC, POC, and the interaction between taxa and POC $\left(\operatorname{adj} R^{2}=0.91\right)$, from which all except POC were significant. The variability in overall $\mathrm{R}$ data was best explained by the variables taxa, temperature, POC, and the interaction term of taxa and temperature $\left(\operatorname{adj} R^{2}=0.77\right)$ from which taxa and temperature significantly influenced overall respiration rates.

\section{Organism-Specific Net Primary Production}

Net production rates of Pocillopora spp. were best explained by the variables light, nutrients, and DOC $\left(\operatorname{adj} R^{2}=0.38\right)$ and significantly increased with increasing light $\left[F_{(1,20)}=\right.$ 6.978, $p=0.0157]$ and DOC levels $\left[F_{(1,20)}=6.766, p=\right.$ $0.0171]$. For production rates of CCA, no combination of the measured parameters could explain the variability in the Pn data. Production rates of turf algae were best explained by the variables temperature, light, nutrients, and DOC (adj $\left.R^{2}=0.33\right)$ and significantly increased with increasing temperature $\left[F_{(1,19)}=\right.$ 7.322, $p=0.0140]$, light $\left[F_{(1,19)}=6.971, p=0.0161\right]$, and nutrients $\left[F_{(1,19)}=4.932, p=0.0387\right]$. Production rates of $C$. sertularioides were best explained by temperature, light, and nutrients $\left(\operatorname{adj} R^{2}=0.43\right)$ and significantly increased with increasing temperature $\left[F_{(1,28)}=13.684, p=0.0009\right]$, light $\left[F_{(1,28)}=6.838, p=0.0142\right]$, and nutrients $\left[F_{(1,19)}=6.953\right.$, $p=0.0135]$. See Supplementary Table 2 for further details of statistical tests.

\section{DISCUSSION}

This study represents one of few field investigations comparing primary production rates of different coral reef primary producers (Wanders, 1976; Eidens et al., 2012, 2014; Naumann et al., 2013). To our knowledge, it is the first study to correlate in-situ organism-specific metabolic rates to seasonal variations in environmental conditions. Our findings characterize the investigated reef as a net autotrophic benthic environment dominated by the scleractinian corals Pocillopora spp. and turf algae, which due to their high production rates are also the major contributors to photosynthetic primary production on the reef. In contrast to previous studies (Eidens et al., 2012, 2014; Jantzen et al., 2013), increased photosynthetic rates of Pocillopora spp. from February to April 2014 suggest a competitive advantage of corals over algae under upwelling conditions. 

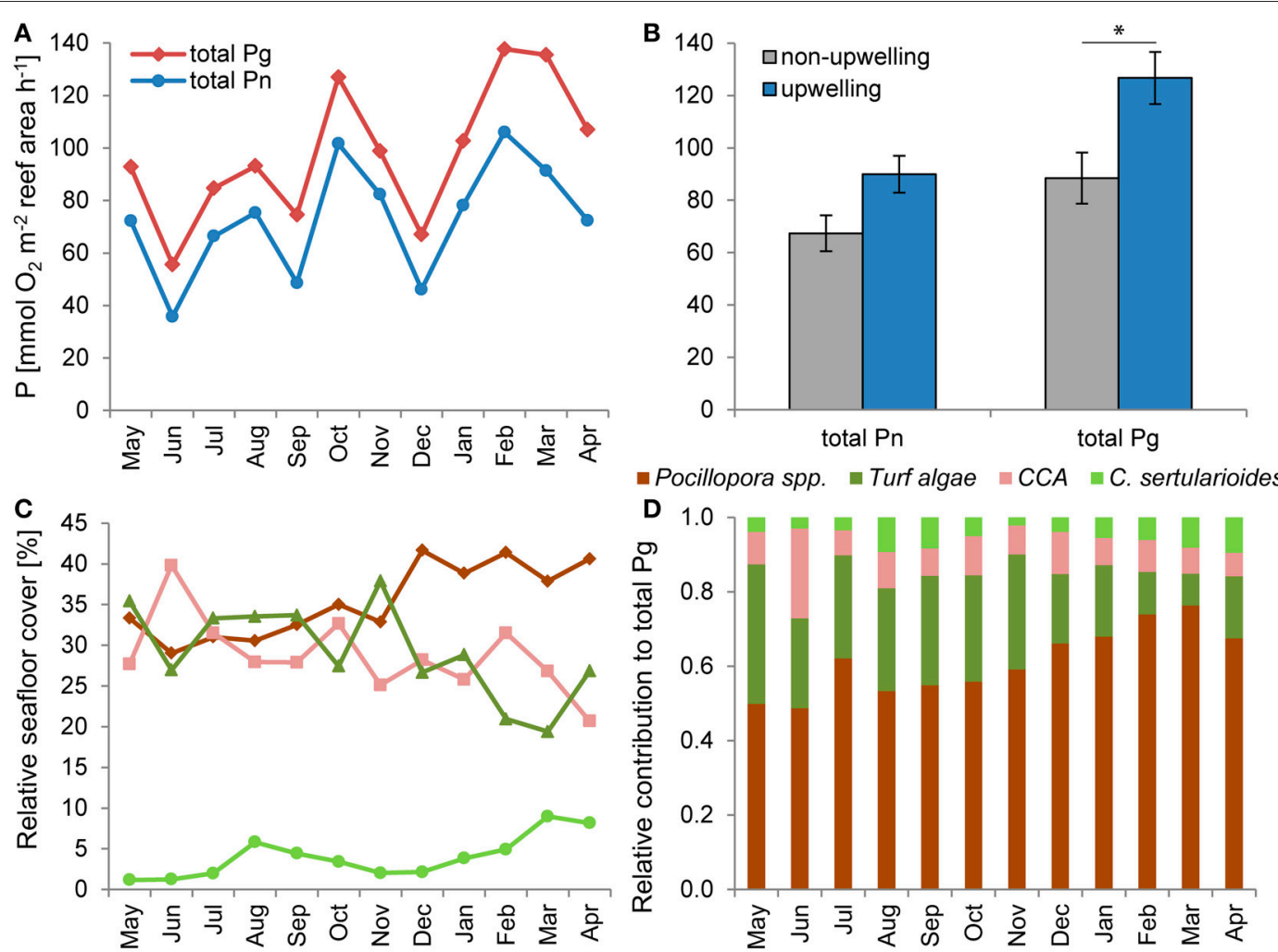

FIGURE 4 | Reef-wide primary production. (A) Total reef-wide net (total Pn) and gross primary production (total Pg) from May 2013 to April 2014 at a monthly temporal resolution and (B) comparing non-upwelling (May 2013-January 2014) and upwelling conditions (February-April 2014). (C) Relative seafloor cover of dominant primary producers over the year of observation and (D) their relative contribution to monthly total Pg calculated from (A, C). ${ }^{\star} P<0.05$.

\section{Organism-Specific Primary Production}

Individual production and respiration rates of corals and CCA obtained during this study were very similar to previous reference studies (Wanders, 1976; Chisholm, 2003; Eidens et al., 2014). Primary production rates of turf algae in comparable studies ranged from 7.6 (Eidens et al., 2014) to $40 \mathrm{mmol} \mathrm{O}_{2} \mathrm{~m}^{-2} \mathrm{~h}^{-1}$ (Wanders, 1976). As turf algae are diverse conglomerates of different filamentous algae and cyanobacteria, it is not surprising that rates differ greatly between studies. In this study, very dense conglomerates of turf algae communities were used, which may explain the relatively high production rates.

Under upwelling conditions, net and gross production rates of Pocillopora spp. increased, while that of all algae taxa remained relatively unchanged. Eidens et al. (2014) found an opposite pattern for the Caribbean with decreased productivity rates of corals and increased rates for turf algae and CCA during upwelling, although nutrient concentrations during upwelling at their study site were lower compared to the present study (Bayraktarov et al., 2014). The stable or even increased production rates of investigated organisms under upwelling conditions suggest that eastern tropical Pacific primary producers are acclimatized to pronounced seasonal variations in water temperature and nutrient availability.

Respiration rates of all taxa increased under upwelling conditions. While this effect was balanced by higher production rates in the coral, the Pn:R ratios of all algal taxa decreased, indicating that the investigated algae may have been subjected to temperature- (Beyers, 1962) or light-stress (Copeland, 1965). The coral Pocillopora spp. on the other hand strongly benefitted from upwelling conditions in terms of productivity. A parallel growth experiment with Pocillopora spp. revealed that $60 \%$ of the annual linear growth of these corals occurred within only 4 months including the upwelling period (December 2013-March 2014; Sánchez-Noguera, unpublished data). This result indicates that the increased production of corals under upwelling conditions also resulted in increased coral growth.

\section{Environmental Factors Driving Primary Production}

Depending on the sensitivity of different organisms to certain environmental factors, upwelling can apparently be beneficial for some primary producers, while decreasing the performance of others. Photosynthetic performance of algal turfs increased 2.0fold in the Caribbean during the upwelling season (Eidens et al., 2014) and 1.4-fold in the Andaman Sea on island sides exposed to large amplitude internal waves (Jantzen et al., 2013), which the authors related to increased nutrient concentrations and water currents. Although Pn rates of turf algae and C. sertularioides in our study were likewise positively correlated to nutrient concentrations, net and gross primary production of these algal taxa was unchanged under upwelling conditions when nutrient concentrations were highest. This lack of organism-response may be due to changes in other abiotic factors that compensated for the positive effects of nutrients. Our results and previous studies 

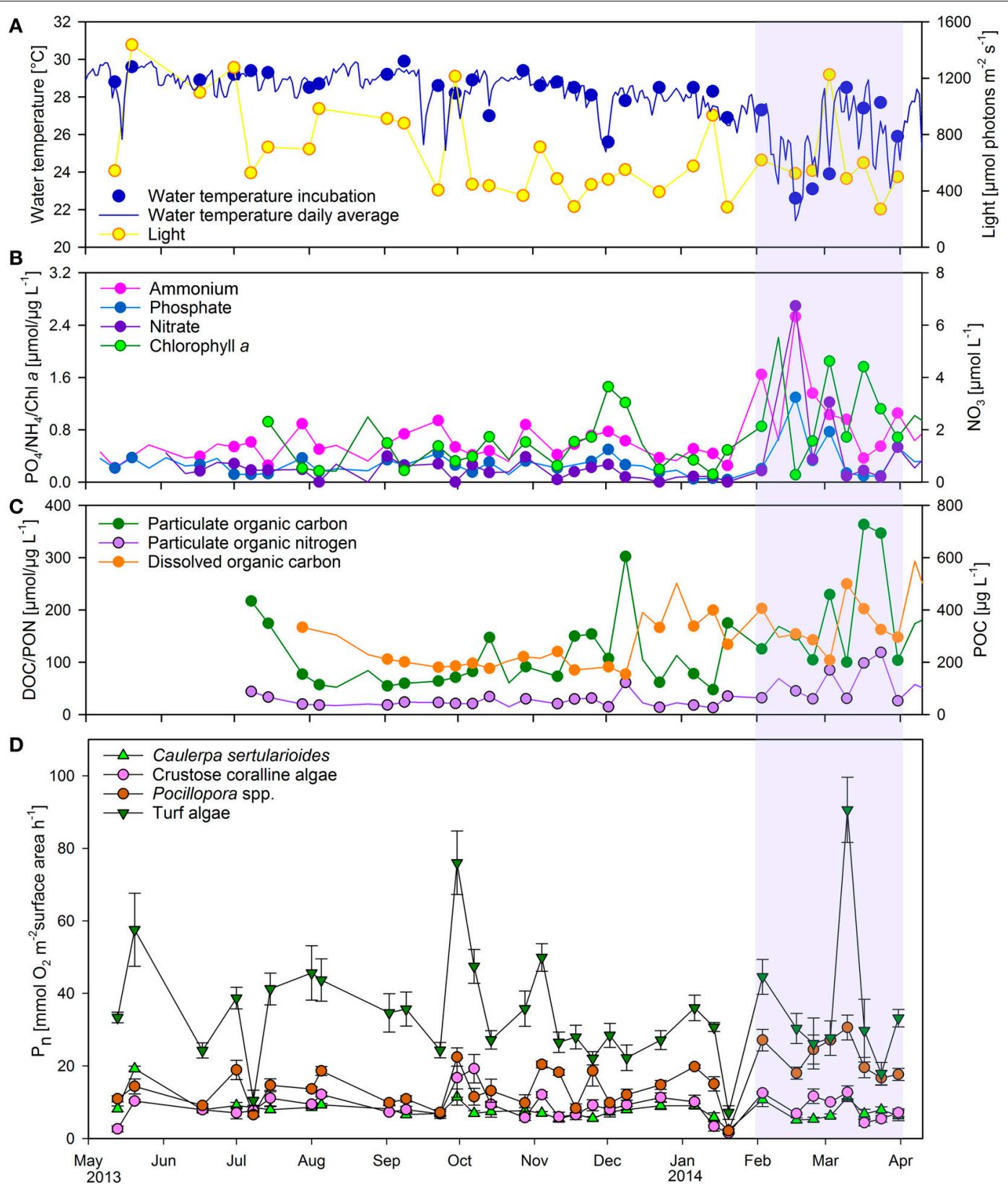

FIGURE 5 | Seasonal changes in water parameters and individual net primary production. (A) Water temperature and light availability in $5 \mathrm{~m}$ water depth, (B) inorganic nutrient concentrations, (C) dissolved and particulate organic matter and (D) net primary production rates of main primary producers on the reef (mean \pm $\mathrm{SE})$. Lines in (A-C) display all available data points while scatter points indicate measurements parallel to incubations which were used for linear model fitting. $P \mathrm{O}_{4}$, phosphate; $\mathrm{NH}_{4}$, ammonium; $\mathrm{Chl}$ a, Chlorophyll a; $\mathrm{NO}_{3}$, nitrate; $\mathrm{DOC}$, dissolved organic carbon; $P O \mathrm{~N}$, particulate organic nitrogen; $P O C$, particulate organic carbon; Pn, net primary production.

showed productivity of turf algae and macroalgae positively correlated with light availability (Gladfelter, 1985; Adey and Goertemiller, 1987) and temperature (Hatcher, 1990; Davison, 1991). While average light availability stayed constant, lower water temperature during upwelling likely reduced the metabolic activity of turf and fleshy macroalgae (Davison, 1991) and thereby mitigated the positive effects of increased nutrient concentrations on algal primary production (Szmant, 1997; Carpenter and Williams, 2007).
In general, most studies showed that corals are at a disadvantage compared to algae when nutrient levels are high (Jompa and McCook, 2002; Haas et al., 2009; Vermeij et al., 2010). The disadvantage of corals was not apparent in the present study, which is likely due to a combination of factors. High nutrient availability may not only benefit algae but also the productivity of corals by increasing their symbiont density and chlorophyll a content (Szmant, 2002). However, Pn rates of Pocillopora spp. in the present study were not correlated to nutrient 
concentrations. This lack of correlation suggests that changes in other upwelling related parameters were responsible for the increased productivity rates of corals under upwelling conditions. In our models, DOC concentrations correlated positively with coral net primary production rates. It is, however, likely that the elevated DOC concentrations are rather a result of increased productivity rates and excess release of organic matter instead of driving primary production. All photosynthesizing benthic organisms release part of their fixed carbon into the water column as DOC, with benthic algae releasing more DOC than corals (Wild et al., 2010; Haas et al., 2011, 2013). Macroalgal labile DOC fuels the growth of heterotrophic microbes associated with corals and algae (Smith et al., 2006; Haas et al., 2013; Nelson et al., 2013), which may negatively affect corals by increasing the dominance of pathogenic bacteria (Kline et al., 2006; Dinsdale et al., 2008; Nelson et al., 2013), or by causing local hypoxia leading to coral tissue mortality (Barott et al., 2009; Wild et al., 2010; Haas et al., 2011). In contrast to these findings, we found DOC concentrations positively correlated with Pocillopora spp. primary production. As Pocillopora spp. was the main contributor to reef-wide benthic net and gross photosynthesis, it is possible that they produced most of the available DOC in the reef water. Coral derived DOC is less bioavailable than algal derived DOC (Haas et al., 2013) and may therefore stay in the reef water for an extended time without negative effects on corals. Further factors may benefit coral primary production during upwelling, such as increased food availability for heterotrophic feeding. Increased heterotrophy may enhance rates of photosynthesis by increasing symbiont density and chlorophyll $a$ content in corals (Dubinsky et al., 1990; Titlyanov et al., 2000; Houlbrèque et al., 2003) and thereby enables acclimation to low water temperatures (Wellington and Glynn, 1983; Manzello, 2010). The ability to feed heterotrophically may therefore partly explain the competitive advantage of corals over benthic algae in terms of primary production during the upwelling season.

Any variability in production rates of CCA could not be explained by the combination of measured parameters. CCA often thrive best in high-energy environments with high herbivorous pressure (Smith et al., 2010; Williams et al., 2013), where primary production may be facilitated by reduced shading from algae and a thin boundary layer which facilitates nutrient delivery and gas exchange (Chisholm, 2003). Taking into account such factors may increase the explanatory power of the models for all taxa and is therefore suggested for future analyses.

\section{Reef-Wide Primary Production}

At the studied reef, Pocillopora spp. contributed most to total reef-wide Pg in both non-upwelling and upwelling season, due to high individual primary production rates, a high benthic coverage, and the coral's structural complexity. Coral cover in the reef was increasing over time, which was driven by high linear growth rates and lateral tissue expansion over existing reef structure (personal observation), while recruitment was negligible (Roth et al., 2015). Dominant contribution of corals to reef-wide Pg was also observed in a Caribbean upwelling system (Eidens et al., 2014). In contrast, turf algae were the
TABLE 3 | Daily total reef primary production in various coral reef ecosystems.

\begin{tabular}{|c|c|c|c|}
\hline \multirow[t]{2}{*}{ Reference } & Total Pg & Total Pn & \multirow[t]{2}{*}{ Reef type and region } \\
\hline & \multicolumn{2}{|c|}{$\left(\mathrm{mmol} \mathrm{O}_{2} \mathrm{~m}^{-2}\right.$ reef area $\left.\mathrm{d}^{-1}\right)$} & \\
\hline Present study & $667-1652$ & $191-916$ & $\begin{array}{l}\text { Reef } 5 \mathrm{~m} \text { depth, Costa } \\
\text { Rica, eastern Pacific }\end{array}$ \\
\hline Wanders, 1976 & 1294 & 531 & $\begin{array}{l}\text { Reef } 0.5-3 \mathrm{~m} \text { depth, } \\
\text { Curaçao, Caribbean }\end{array}$ \\
\hline Kinsey, 1985 & $333-1665$ & & $\begin{array}{l}\text { Reef flat, various } \\
\text { locations }\end{array}$ \\
\hline $\begin{array}{l}\text { Adey and } \\
\text { Steneck, } 1985\end{array}$ & $626-1275$ & $225-938$ & $\begin{array}{l}\text { Fore reef } 6 \mathrm{~m} \text { depth, St. } \\
\text { Croix, Caribbean }\end{array}$ \\
\hline Hatcher, 1988 & $167-583$ & $-83-425$ & $\begin{array}{l}\text { Fore reef, various } \\
\text { locations }\end{array}$ \\
\hline Eidens et al., 2012 & $250-483$ & $125-272$ & $\begin{array}{l}\text { Reef } 10 \mathrm{~m} \text { depth, } \\
\text { Colombia, Caribbean }\end{array}$ \\
\hline Eidens et al., 2014 & 250-305 & $103-169$ & $\begin{array}{l}\text { Reef } 10 \mathrm{~m} \text { depth, } \\
\text { Colombia, Caribbean }\end{array}$ \\
\hline
\end{tabular}

Minimum and maximum values of total reef-wide gross (total Pg) and net primary production (total $\mathrm{Pn}$ ) for different reef locations. If necessary, original units were converted to $\mathrm{O}_{2}$ estimates assuming a $\mathrm{C}: \mathrm{O}_{2}$ metabolic quotient equal to one.

main contributors to reef primary production in areas exposed to large amplitude internal waves (Jantzen et al., 2013) or rain-induced nutrient plumes (Den Haan, 2015) due to high individual photosynthetic rates of turf algae in combination with high relative substrate cover.

It has been recognized that daily reef primary production varies dramatically among reefs, sometimes by $1-2$ orders of magnitude (Adey and Steneck, 1985; Hatcher, 1990). Besides large differences in environmental settings, this variation may partly be due to different measuring techniques and calculation methods, especially when extrapolating measured values to daily production rates. Despite these uncertainties we want to provide a comparison with reef-wide production rates from different locations as, until now, no primary production rates have been published for the eastern tropical Pacific. If we assume a 12:12 h day/night cycle, as typical for the tropics, and extrapolate our hourly values to daily estimates of reef-wide $\mathrm{Pg}$ (total $\mathrm{Pg} \mathrm{h}^{-1}$ $\times 12 \mathrm{~h}$ sunlight) and $\mathrm{Pn}$ (total $\mathrm{Pn} \mathrm{h}^{-1} \times 12 \mathrm{~h}$ sunlight-total $\mathrm{R} \mathrm{h}^{-1} \times 12 \mathrm{~h}$ night) we end up with magnitudes of total reef production in the upper range of most comparable studies and considerably higher than some (Table 3). Because incubations took place at relatively high light intensities around midday, realistic daily values are likely lower than calculated by simple extrapolation to $12 \mathrm{~h}$, but still hint to a highly productive reef system in the upwelling region of Papagayo. Differences to the studies of Hatcher $(1990)$ and Eidens et al. $(2012,2014)$ could be mainly due to water depth effects, as those studies were conducted at around $10 \mathrm{~m}$ water depth where the light availability and therefore primary production is lower. Values from a reef in $6 \mathrm{~m}$ depth are very similar to our estimates (Adey and Steneck, 1985). The higher range of total daily Pg and Pn data in our study compared to studies by Hatcher (1990) and Eidens et al. $(2012,2014)$ might be attributed to their much smaller sample size ( $n=4$ compared to $n=12)$. 
It has been suggested that Caribbean reefs, in general, are more productive than Pacific reefs (Adey and Steneck, 1985; Hatcher, 1990). The present study does not confirm this hypothesis; in fact, reef production was higher than in several reef systems in the Caribbean (Table 3). The relatively high productivity observed at the study site may be due to the upwelling, which usually supports very productive ecosystems (Birkeland, 1988). This assumption is supported by higher total $\mathrm{Pn}$ and $\mathrm{Pg}$ during upwelling. Another reason for the high productivity compared to other ecosystems may be the structural complexity of the dominating coral Pocillopora spp., as the increased light capturing capabilities of branching corals facilitate higher production rates compared to massive or plating growth forms (Smith, 1981).

Compared to prior studies which reported two-fold higher benthic primary production in summer (Kinsey, 1977, 1985; Smith, 1981) or during upwelling (Eidens et al., 2012), the differences in total Pn and Pg comparing non-upwelling and upwelling conditions in the present study were relatively low. The high and stable reef primary production suggests acclimation mitigated responses of the benthic community to seasonal variations in water parameters.

\section{Outlook}

Future global change will likely decrease carbonate saturation and increase the frequency of warming events on coral reefs worldwide (Hoegh-Guldberg et al., 2007; Pandolfi et al., 2011). A recent study modeling future environmental conditions on coral reefs demonstrated that marginal reef ecosystems at high latitudes and in the eastern tropical Pacific perform well in climate change scenarios (Freeman, 2015). The positive projections for marginal reef habitats may partly be due to the fact that coral populations acclimatized to naturally large variations in local conditions may be more resilient to future environmental changes (Brown, 1997; Freeman et al., 2012). The constantly high total benthic productivity at Matapalo reef suggests a generally high resilience of local benthic communities against present and maybe also future environmental fluctuations. The upwelling could furthermore lower high temperature and radiative stress during warming events (Wall et al., 2015). It is, however, likely that interannual variations in conditions affect the productivity of eastern tropical Pacific coral reefs as it was shown for

\section{REFERENCES}

Adey, W. H., and Goertemiller, T. (1987). Coral reef algal turfs: master producers in nutrient poor seas. Phycologia 26, 374-386. doi: 10.2216/i0031-8884-263-374.1

Adey, W. H., and Steneck, R. S. (1985). "Highly productive eastern Caribbean reefs: synergistic effects of biological, chemical, physical, and geological factors," in The Ecology of Deep and Shallow Coral Reefs. Symposia Series for Undersea Research, ed M. L. Reaka (Rockville), 163-187. Available online at: http://www. aoml.noaa.gov/general/lib/CREWS/Cleo/St.\%20Croix/salt_river45.pdf

Alcala, M. L. R., and Vogt, H. (1997). "Approximation of coral reef surfaces using standardised growth forms and video counts," in Proceedings of the 8th International Coral Reef Symposium (Panamá, FL), 1453-1458. Available online at: http://www.reefbase.org/resource_center/publication/icrs.aspx

Alfaro, E. J., Cortés, J., Alvarado, J. J., Jiménez, C., León, A., Sánchez-Noguera, C., et al. (2012). Clima y temperatura sub-superficial del mar en Bahía Culebra, the Caribbean (Eidens et al., 2014). This variability should be investigated by repeated incubation experiments over several seasons and years. It would be interesting also to investigate how total reef primary production relates to reef accretion and erosion, and how multiannual stressors such as El Niño events or harmful algae blooms affect primary production on the reef. Only reefs with a positive and stable net growth despite strong fluctuations in environmental parameters may be less susceptible to future environmental changes.

\section{AUTHOR CONTRIBUTIONS}

The study was designed by IS and CW. TR and JC contributed to the study's concept. The research was performed by IS, CS, and FR. The data was analyzed by IS and the paper was written by IS with support of all authors. All authors approved the final version of the manuscript.

\section{FUNDING}

This study was funded by the Leibniz Association as part of the Leibniz Center for Tropical Marine Ecology (ZMT) project COSTACID.

\section{ACKNOWLEDGMENTS}

Field work was conducted under permits issued by the National System of Conservation Areas (SINAC) of Costa Rica (permit No: 019-2013-SINAC).We thank I. Gottwald for assistance in the field, and the Centro de Investigación en Ciencias del Mar y Limnología (CIMAR), Universidad de Costa Rica, as well as the RIU Guanacaste for logistic support. We also thank three anonymous reviewers as well as the associated editor Thomas Frazer for constructive comments on the manuscript.

\section{SUPPLEMENTARY MATERIAL}

The Supplementary Material for this article can be found online at: http://journal.frontiersin.org/article/10.3389/fmars. 2015.00113

Golfo de Papagayo, Costa Rica. Rev. Biol. Trop. 60(Suppl. 2), 159-171. doi: 10.15517/rbt.v60i2.20000

Al-Horani, F. A., Al-Moghrabi, S. M., and De Beer, D. (2003). The mechanism of calcification and its relation to photosynthesis and respiration in the scleractinian coral Galaxea fascicularis. Mar. Biol. 142, 419-426. doi: 10.1007/s00227-002-0981-8

Amador, J. A., Alfaro, E. J., Lizano, O. G., and Magaña, V. O. (2006). Atmospheric forcing of the eastern tropical Pacific: a review. Prog. Oceanogr. 69, 101-142. doi: 10.1016/j.pocean.2006.03.007

Arar, E. J., and Collins, G. B. (1997). Method 445.0: In vitro Determination of Chlorophyll $a$ and Pheophytin a in Marine and Freswater Algae by Fluorescence. United States Environ. Prot. Agency, Off. Res. Dev. Natl. Expo. Res. Lab. Available online at: http://monitoringprotocols.pbworks.com/f/EPA445.pdf

Barott, K., Smith, J., Dinsdale, E., Hatay, M., Sandin, S., and Rohwer, F. (2009). Hyperspectral and physiological analyses of coral-algal interactions. PLoS ONE 4:e8043. doi: 10.1371/journal.pone.0008043 
Bayraktarov, E., Pizarro, V., and Wild, C. (2014). Spatial and temporal variability of water quality in the coral reefs of Tayrona National Natural Park, Colombian Caribbean. Environ. Monit. Assess. 186, 3641-3659. doi: 10.1007/s10661-0143647-3

Beyers, R. J. (1962). Relationship between temperature and the metabolism of experimental ecosystems. Science 136, 980-982. doi: $10.1126 /$ science.136.3520.980

Birkeland, C. (1988). "Geographic comparisons of coral-reef community processes," in Proceedings of the 6th International Coral Reef Symposium, Vol 1, 211-220. Available online at: http://www.reefbase. org/resource_center/publication/icrs.aspx

Brown, B. E. (1997). "Disturbances to reefs in recent times," in Life and Death of Coral Reefs, ed C. Birkeland (New York, NY: Chapman \& Hall), 354-379. Available online at: http://www.marine.usf.edu/ reefslab/documents/evol_ecol2007/BBROWN\%28inpress\%29.pdf

Carpenter, R. C. (1990). Competition among marine macroalgae: a physiological perspective. J. Phycol. 26, 6-12. doi: 10.1111/j.0022-3646.1990.00006.x

Carpenter, R. C., and Williams, S. L. (2007). Mass transfer limitation of photosynthesis of coral reef algal turfs. Mar. Biol. 151, 435-450. doi: 10.1007/s00227-006-0465-3

Chapin, F. S., Matson, P. A., and Mooney, H. A. (2002). Principles of Terrestrial Ecosystem Ecology. New York, NY: Springer-Verlag Inc.

Chisholm, J. R. M. (2003). Primary productivity of reef-building crustose coralline algae. Limnol. Oceanogr. 48, 1376-1387. doi: 10.4319/lo.2003.48.4.1376

Copeland, B. J. (1965). Evidence for regulation of community metabolism in a marine ecosystem. Ecology 46, 563-564. doi: 10.2307/1934899

Cortés, J., Samper-Villarreal, J., and Bernecker, A. (2014). Seasonal phenology of Sargassum liebmannii J. Agardh (Fucales, Heterokontophyta) in an upwelling area of the Eastern Tropical Pacific. Aquat. Bot. 119, 105-110. doi: 10.1016/j.aquabot.2014.08.009

D'Croz, L., and O'Dea, A. (2007). Variability in upwelling along the Pacific shelf of Panama and implications for the distribution of nutrients and chlorophyll. Estuar. Coast. Shelf Sci. 73, 325-340. doi: 10.1016/j.ecss.2007.01.013

Davison, I. R. (1991). Environmental effects on algal photosynthesis: temperature. J. Phycol. 27, 2-8. doi: 10.1111/j.0022-3646.1991.00002.x

Delgado, O., and Lapointe, B. E. (1994). Nutrient-limited productivity of calcareous versus fleshy macroalgae in a eutrophic, carbonate-rich tropical marine environment. Coral Reefs 13, 151-159. doi: 10.1007/BF00 301191

Den Haan, J. (2015). Effects of Nutrient Enrichment on the Primary Producers of a Degraded Coral Reef. PhD. thesis, Dissertations University, Amsterdam. Available online at: http://hdl.handle.net/11245/1.471226

Dinsdale, E. A., Pantos, O., Smriga, S., Edwards, R. A., Angly, F., Wegley, L., et al. (2008). Microbial ecology of four coral atolls in the Northern Line Islands. PLoS ONE 3:e1584. doi: 10.1371/journal.pone.0001584

Dubinsky, Z., Stambler, N., Ben-Zion, M., Mccloskey, L. R., Muscatine, L., and Falkowski, P. G. (1990). The effect of external nutrient resources on the optical properties and photosynthetic efficiency of Stylophora pistillata. Proc. R. Soc. B Biol. Sci. 239, 231-246. doi: 10.1098/rspb.1990.0015

Eidens, C., Bayraktarov, E., Hauffe, T., Pizarro, V., Wilke, T., and Wild, C. (2014). Benthic primary production in an upwelling-influenced coral reef, Colombian Caribbean. PeerJ 2, e554. doi: 10.7717/peerj.554

Eidens, C., Bayraktarov, E., Pizarro, V., Wilke, T., and Wild, C. (2012). "Seasonal upwelling stimulates primary production of Colombian Caribbean coral reefs," in Proceedings of the 12th International Coral Reef Symposium (Cairns, QLD), ICRS2012_6C_1. Available online at: http://www.reefbase.org/resource_center/publication/icrs.aspx

Fassbender, A. J., Sabine, C. L., Feely, R. A., Langdon, C., and Mordy, C. W. (2011). Inorganic carbon dynamics during northern California coastal upwelling. Cont. Shelf Res. 31, 1180-1192. doi: 10.1016/j.csr.2011.04.006

Fernández-García, C., Cortés, J., Alvarado, J. J., and Nivia-Ruiz, J. (2012). Physical factors contributing to the benthic dominance of the alga Caulerpa sertularioides (Caulerpaceae, Chlorophyta) in the upwelling Bahía Culebra, north Pacific of Costa Rica. Rev. Biol. Trop. 60(Suppl. 2), 93-107. doi: 10.15517/rbt.v60i2.19970

Fiedler, P. C., and Talley, L. D. (2006). Hydrography of the eastern tropical Pacific: a review. Prog. Oceanogr. 69, 143-180. doi: 10.1016/j.pocean.2006. 03.008
Freeman, L. A. (2015). Robust performance of marginal Pacific coral reef habitats in future climate scenarios. PLOS ONE 10:e0128875. doi: 10.1371/journal.pone.0128875

Freeman, L. A., Miller, A. J., Norris, R. D., and Smith, J. E. (2012). Classification of remote Pacific coral reefs by physical oceanographic environment. J. Geophys. Res. Ocean. 117, 1-10. doi: 10.1029/2011jc007099

García-Robledo, E., Corzo, A., and Papaspyrou, S. (2014). A fast and direct spectrophotometric method for the sequential determination of nitrate and nitrite at low concentrations in small volumes. Mar. Chem. 162, 30-36. doi: 10.1016/j.marchem.2014.03.002

Gattuso, J.-P., Frankignoulle, M., and Wollast, R. (1998). Carbon and carbonate metabolism in coastal aquatic ecosystems. Annu. Rev. Ecol. Syst. 29, 405-434. doi: 10.1146/annurev.ecolsys.29.1.405

Gladfelter, E. H. (1985). "Metabolism, calcification and carbon production. II Organism-level studies," in Proceedings of the 5th International Coral Reef Congress (Tahiti). 4, 527-539. Available online at: http://www.reefbase. org/resource_center/publication/icrs.aspx

Glynn, P. W., and D'Croz, L. (1990). Experimental evidence for high temperature stress as the cause of El Niño-coincident coral mortality. Coral Reefs 8, 181-191.

Haas, A. F., Al-Zibdah, M., and Wild, C. (2009). Effect of inorganic and organic nutrient addition on coral-algae assemblages from the Northern Red Sea. J. Exp. Mar. Bio. Ecol. 380, 99-105. doi: 10.1016/j.jembe.2009.09.005

Haas, A. F., Nelson, C. E., Rohwer, F., Wegley-Kelly, L., Quistad, S. D., Carlson, C. A., et al. (2013). Influence of coral and algal exudates on microbially mediated reef metabolism. PeerJ 1, e108. doi: 10.7717/peerj.108

Haas, A. F., Nelson, C. E., Wegley-Kelly, L., Carlson, C. A., Rohwer, F., Leichter, J. J., et al. (2011). Effects of coral reef benthic primary producers on dissolved organic carbon and microbial activity. PLOS ONE 6:e27973. doi: 10.1371/journal.pone.0027973

Hallock, P., and Schlager, W. (1986). Nutrient excess and the demise of coral reefs and carbonate platforms. Palaios 1, 389-398. doi: $10.2307 / 3514476$

Hansell, D. A. (1993). Results and observations from the measurement of DOC and DON in seawater using a high-temperature catalytic oxidation technique. Mar. Chem. 41, 195-202. doi: 10.1016/0304-4203(93) 90119-9

Hatcher, B. G. (1988). Reef primary productivity: a beggar's banquet. Trends Ecol. Evol. 3, 106-111. doi: 10.1016/0169-5347(88)90117-6

Hatcher, B. G. (1990). Coral reef primary productivity. A hierarchy of pattern and process. Trends Ecol. Evol. 5, 149-155. doi: 10.1016/0169-5347(90)90221-X

Hoegh-Guldberg, O., Mumby, P. J., Hooten, A. J., Steneck, R. S., Greenfield, P., Gomez, E., et al. (2007). Coral reefs under rapid climate change and ocean acidification. Science 318, 1737-1742. doi: 10.1126/science.1152509

Holmes, R. M., Aminot, A., Kérouel, R., Hooker, B. A., and Peterson, B. J. (1999). A simple and precise method for measuring ammonium in marine and freshwater ecosystems. Can. J. Fish. Aquat. Sci. 56, 1801-1808. doi: 10.1139/ f99-128

Houlbrèque, F., Tambutté, E., and Ferrier-Pagès, C. (2003). Effect of zooplankton availability on the rates of photosynthesis, and tissue and skeletal growth in the scleractinian coral Stylophora pistillata. J. Exp. Mar. Bio. Ecol. 296, 145-166. doi: 10.1016/S0022-0981(03)00259-4

Hughes, T. P., Baird, A. H., Bellwood, D. R., Card, M., Connolly, S. R., Folke, C., et al. (2003). Climate change, human impacts, and the resilience of coral reefs. Science 301, 929-933. doi: 10.1126/science.1085046

Hughes, T. P., Graham, N. A. J., Jackson, J. B. C., Mumby, P. J., and Steneck, R. S. (2010). Rising to the challenge of sustaining coral reef resilience. Trends Ecol. Evol. 25, 633-642. doi: 10.1016/j.tree.2010.07.011

Jantzen, C., Schmidt, G. M., Wild, C., Roder, C., Khokiattiwong, S., and Richter, C. (2013). Benthic reef primary production in response to large amplitude internal waves at the Similan Islands (Andaman Sea, Thailand). PLoS ONE 8:e81834. doi: 10.1371/journal.pone.0081834

Jiménez, C. (2001). Seawater temperature measured at the surface and at two depths (7 and $12 \mathrm{~m}$ ) in one coral reef at Culebra Bay, Gulf of Papagayo, Costa Rica. Rev. Biol. Trop. 49(Suppl. 2), 153-161.

Jompa, J., and McCook, L. J. (2002). The effects of nutrients and herbivory on competition between a hard coral (Porites cylindrica) and a brown alga (Lobophora variegata). Limnol. Oceanogr. 47, 527-534. doi: 10.4319/lo.2002.47.2.0527 
Kinsey, D. W. (1977). "Seasonality and zonation in coral reef productivity and calcification," in Proceedings of the 3rd International Coral Reef Symposium (Miami, FL), 383-388. Available online at: http://www.reefbase.org/ resource_center/publication/icrs.aspx

Kinsey, D. W. (1985). "Metabolism, calcification and carbon production. I Systems level studies," in Proceedings of the 5th International Coral Reef Congress (Tahiti), 4, 505-526. Available online at: http://www.reefbase.org/ resource_center/publication/icrs.aspx

Kirk, J. T. O. (1994). Light and Photosynthesis in Aquatic Ecosystems, 2nd Edn. Cambridge, UK: Cambridge University Press.

Kline, D. I., Kuntz, N. M., Breitbart, M., Knowlton, N., and Rohwer, F. (2006). Role of elevated organic carbon levels and microbial activity in coral mortality. Mar. Ecol. Prog. Ser. 314, 119-125. doi: 10.3354/meps314119

Larned, S. T. (1998). Nitrogen- versus phosphorus-limited growth and sources of nutrients for coral reef macroalgae. Mar. Biol. 132, 409-421. doi: $10.1007 / \mathrm{s} 002270050407$

Long, M. H., Rheuban, J. E., Berg, P., and Zieman, J. C. (2012). A comparison and correction of light intensity loggers to photosynthetically active radiation sensors. Limnol. Oceanogr. Methods 10, 416-424. doi: 10.4319/lom.2012. 10.416

Manzello, D. P. (2010). Coral growth with thermal stress and ocean acidification: lessons from the eastern tropical Pacific. Coral Reefs 29, 749-758. doi: 10.1007/s00338-010-0623-4

Mass, T., Genin, A., Shavit, U., Grinstein, M., and Tchernov, D. (2010). Flow enhances photosynthesis in marine benthic autotrophs by increasing the efflux of oxygen from the organism to the water. Proc. Natl. Acad. Sci. U.S.A. 107, 2527-2531. doi: 10.1073/pnas.0912348107

McCreary, J. P., Lee, H. S., and Enfield, D. B. (1989). The response of the coastal ocean to strong offshore winds: with application to circulations in the Gulfs of Tehuantepec and Papagayo. J. Mar. Res. 47, 81-109. doi: $10.1357 / 002224089785076343$

Murphy, J., and Riley, J. P. (1962). A modified single solution method for the determination of phosphate in natural waters. Anal. Chim. Acta 27, 31-36. doi: 10.1016/S0003-2670(00)88444-5

Muscatine, L., Falkowski, P. G., Porter, J. W., and Dubinsky, Z. (1984). Fate of photosynthetic fixed carbon in light- and shade-adapted colonies of the symbiotic coral Stylophora pistillata. Proc. R. Soc. B Biol. Sci. 222, 181-202. doi: 10.1098/rspb.1984.0058

Muscatine, L., and Porter, J. W. (1977). Reef corals: mutualistic symbioses adapted to nutrient-poor environments. Bioscience 27, 454-460. doi: 10.2307/ 1297526

Naumann, M. S., Jantzen, C., Haas, A. F., Iglesias-Prieto, R., and Wild, C. (2013). Benthic primary production budget of a Caribbean reef lagoon (Puerto Morelos, Mexico). PLoS ONE 8:e82923. doi: 10.1371/journal.pone. 0082923

Naumann, M. S., Niggl, W., Laforsch, C., Glaser, C., and Wild, C. (2009). Coral surface area quantification-evaluation of established techniques by comparison with computer tomography. Coral Reefs 28, 109-117. doi: 10.1007/s00338-0080459-3

Nelson, C. E., Goldberg, S. J., Wegley Kelly, L., Haas, A. F., Smith, J. E., Rohwer, F., et al. (2013). Coral and macroalgal exudates vary in neutral sugar composition and differentially enrich reef bacterioplankton lineages. ISME J. 7, 962-979. doi: 10.1038/ismej.2012.161

Odum, H. T., and Odum, E. P. (1955). Trophic structure and productivity of a windward coral reef community on eniwetok atoll. Ecol. Monogr. 25, 291-320. doi: $10.2307 / 1943285$

Pandolfi, J. M., Connolly, S. R., Marshall, D. J., and Cohen, A. L. (2011). Projecting coral reef futures under global warming and ocean acidification. Science 333, 418-422. doi: 10.1126/science. 1204794

Pennington, J. T., Mahoney, K. L., Kuwahara, V. S., Kolber, D. D., Calienes, R., and Chavez, F. P. (2006). Primary production in the eastern tropical Pacific: a review. Prog. Oceanogr. 69, 285-317. doi: 10.1016/j.pocean.2006. 03.012

R Core Team (2014). R: A Language and Environment for Statistical Computing. Vienna: R Foundation for Statistical Computing. Available online at: http:// www.R-project.org/

Rixen, T., Jiménez, C., and Cortés, J. (2012). Impact of upwelling events on the sea water carbonate chemistry and dissolved oxygen concentration in the Gulf of Papagayo (Culebra Bay), Costa Rica: implications for coral reefs. Rev. Biol. Trop. 60(Suppl. 2), 187-195. doi: 10.15517/rbt.v60i2. 20004

Roder, C., Jantzen, C., Schmidt, G. M., Kattner, G., Phongsuwan, N., and Richter, C. (2011). Metabolic plasticity of the corals Porites lutea and Diploastrea heliopora exposed to large amplitude internal waves. Coral Reefs 30, 57-69. doi: 10.1007/s00338-011-0722-x

Rogers, C. S., Ginger, G., Marie, G., Hillis, Z. M., and Franke, M. A. (1994). Coral Reef Monitoring Manual for the Caribbean and Western Atlantic. National Park Service, Virgin Islands National Park, St. John, US. Available online at: http:// hdl.handle.net/2075/119

Roth, F., Stuhldreier, I., Sánchez-Noguera, C., Morales-Ramírez, Á., and Wild, C. (2015). Effects of simulated overfishing on the succession of benthic algae and invertebrates in an upwelling-influenced coral reef of Pacific Costa Rica. J. Exp. Mar. Bio. Ecol. 468, 55-66. doi: 10.1016/j.jembe.2015.03.018

Saxby, T., Dennison, W., and Hoegh-Guldberg, O. (2003). Photosynthetic responses of the coral Montipora digitata to cold temperature stress. Mar. Ecol. Prog. Ser. 248, 85-97. doi: 10.3354/meps 248085

Schaffelke, B. (1999). Short-term nutrient pulses as tools to assess responses of coral reef macroalgae to enhanced nutrient availability. Mar. Ecol. Prog. Ser. 182, 305-310. doi: 10.3354/meps182305

Schrameyer, V., Wangpraseurt, D., Hill, R., Kühl, M., Larkum, A. W. D., and Ralph, P. J. (2014). Light respiratory processes and gross photosynthesis in two scleractinian corals. PLoS ONE 9:e110814. doi: 10.1371/journal.pone. 0110814

Smith, J. E., Hunter, C. L., and Smith, C. M. (2010). The effects of top-down versus bottom-up control on benthic coral reef community structure. Oecologia 163 , 497-507. doi: 10.1007/s00442-009-1546-z

Smith, J. E., Shaw, M., Edwards, R. A., Obura, D., Pantos, O., Sala, E., et al (2006). Indirect effects of algae on coral: algae-mediated, microbe-induced coral mortality. Ecol. Lett. 9, 835-845. doi: 10.1111/j.1461-0248.2006.00937.x

Smith, S. V. (1981). The Houtman Abrolhos Islands: carbon metabolism of coral reefs at high altitude. Limnol. Oceanogr. 26, 612-621. doi: 10.4319/lo.1981.26.4.0612

Stuhldreier, I., Sánchez-Noguera, C., Rixen, T., Cortés, J., Morales, A., and Wild, C. (2015). Effects of seasonal upwelling on inorganic and organic matter dynamics in the water column of eastern Pacific coral reefs. PLoS ONE. 10:e0142681. doi: 10.1371/journal.pone.0142681

Szmant, A. M. (1997). "Nutrient effects on coral reefs: a hypothesis on the importance of topographic and trophic complexity to reef nutrient dynamics," in Proceedings of the 8th International Coral Reef Symposium, Panamá, 2, 1527-1532. Available online at: http://www.reefbase. org/resource_center/publication/icrs.aspx

Szmant, A. M. (2002). Nutrient enrichment on coral reefs: is it a major cause of coral reef decline? Estuaries 25, 743-766. doi: 10.1007/BF02804903

Taylor, B. W., Keep, C. F., Hall, R. O. Jr., Koch, B. J., Tronstad, L. M., Flecker, A. S., et al. (2007). Improving the fluorometric ammonium method: matrix effects, background fluorescence, and standard additions. J. North Am. Benthol. Soc. 26, 167-177. doi: 10.1899/0887-3593(2007)26[167:ITFAMM]2.0.CO;2

Titlyanov, E., Bil, K., Fomina, I., Titlyanova, T., Leletkin, V., Eden, N., et al. (2000). Effects of dissolved ammonium addition and host feeding with Artemia salina on photoacclimation of the hermatypic coral Stylophora pistillata. Mar. Biol. 137, 463-472. doi: 10.1007/s002270000370

U.S. Environmental Protection Agency (1983). "Method 415.1: determination of total organic carbon in water using combustion or oxidation," in Methods for the Chemical Analysis of Water and Wastes. Washington, DC: Office of Research and Development.

Valiela, I. (1995). Marine Ecological Processes, 2nd Edn. Berlin: Springer-Verlag.

Van Duin, E. H. S., Blom, G., Los, F. J., Maffione, R., Zimmerman, R., Cerco, C. F., et al. (2001). Modeling underwater light climate in relation to sedimentation, resuspension, water quality and autotrophic growth. Hydrobiologia 444, 25-42. doi: 10.1023/A:1017512614680

Van Tussenbroek, B. I. (2011). Dynamics of seagrasses and associated algae in coral reef lagoons. Hidrobiológica 21, 293-310.

Vermeij, M. J. A., van Moorselaar, I., Engelhard, S., Hörnlein, C., Vonk, S. M., and Visser, P. M. (2010). The effects of nutrient enrichment and herbivore abundance on the ability of turf algae to overgrow coral in the Caribbean. PLoS ONE 5:e14312. doi: 10.1371/journal.pone.0014312 
Wall, M., Putchim, L., Schmidt, G. M., Jantzen, C., Khokiattiwong, S., and Richter, C. (2015). Large-amplitude internal waves benefit corals during thermal stress. Proc. R. Soc. B 282, 20140650. doi: 10.1098/rspb.2014.0650

Wanders, J. B. W. (1976). The role of benthic algae in the shallow reef of Curaçao (Netherlands Antilles). I: primary productivity in the coral reef. Aquat. Bot. 2, 235-270. doi: 10.1016/0304-3770(76)90023-1

Wellington, G. M., and Glynn, P. W. (1983). Environmental influences on skeletal banding in eastern Pacific (Panama) corals. Coral Reefs 1, 215-222. doi: 10.1007/BF00304418

Wild, C., Hoegh-Guldberg, O., Naumann, M., Colombo-Palotta, M. F., Ateweberhan, M., Fitt, W. K., et al. (2011). Climate change impedes scleractinian corals as primary reef ecosystem engineers. Mar. Freshw. Res. 62, 205-215. doi: 10.1071/MF10254

Wild, C., Niggl, W., Naumann, M. S., and Haas, A. F. (2010). Organic matter release by Red Sea coral reef organisms - potential effects on microbial activity and in situ $\mathrm{O}_{2}$ availability. Mar. Ecol. Prog. Ser. 411, 61-71. doi: 10.3354/meps08653
Williams, G. J., Smith, J. E., Conklin, E. J., Gove, J. M., Sala, E., and Sandin, S. A. (2013). Benthic communities at two remote Pacific coral reefs: effects of reef habitat, depth, and wave energy gradients on spatial patterns. PeerJ 1, e81. doi: $10.7717 /$ peerj. 81

Conflict of Interest Statement: The authors declare that the research was conducted in the absence of any commercial or financial relationships that could be construed as a potential conflict of interest.

Copyright () 2015 Stuhldreier, Sánchez-Noguera, Roth, Cortés, Rixen and Wild. This is an open-access article distributed under the terms of the Creative Commons Attribution License (CC BY). The use, distribution or reproduction in other forums is permitted, provided the original author(s) or licensor are credited and that the original publication in this journal is cited, in accordance with accepted academic practice. No use, distribution or reproduction is permitted which does not comply with these terms. 